\title{
Takotsubo syndrome associated with cardioversion: a systematic review
}

\author{
Tayyab Ali Waheed ${ }^{1}$, Usama Nasir ${ }^{2 *} \mathbb{C}$, Ansar Aziz ${ }^{3}$, Haseeb Chaudhary² and Anthony Donato ${ }^{2,4}$
}

\begin{abstract}
Background: Direct current cardioversion is a well-established and safe procedure to restore normal sinus rhythm for atrial and ventricular arrhythmias. Takotsubo syndrome has been rarely described with cardioversion. We reviewed the literature for descriptions of Takotsubo syndrome associated with the stress of cardioversion, to better understand its risks.

Methods: We queried MEDLINE, EMBASE, Google Scholar and Cochrane for cases of Takotsubo syndrome secondary to synchronized cardioversion as defined by Mayo Clinic Diagnostic Criteria.

Results: We identified 11 cases of cardioversion-associated Takotsubo syndrome. Average age was 76 years (range: 61-87 years) and most (10 out of 11,91\%) were female. Diagnosis was made soon after cardioversion (median: $10 \mathrm{~h}$, range: $0-48$ h). Only 2 of 11 had ST elevations noted, while apical ballooning was noted in all cases. Pulmonary edema developed in 6 and cardiogenic shock developed in 5 patients. The median recovery time was 7 days (range: 3-11).
\end{abstract}

Conclusions: Cardioversion-associated TS has an overall favorable outcome with complete recovery in most cases. A higher risk of this complication may exist for elderly females undergoing synchronized cardioversion.

Keywords: Takotsubo Syndrome, Takotsubo cardiomyopathy, Cardioversion, Cardiogenic shock

\section{Introduction}

Direct current cardioversion is a well-established, safe, and effective procedure to restore normal sinus rhythm for both atrial and ventricular arrhythmias [1]. Although thromboembolism is the most feared complication, hypotension and Takotsubo syndrome (TS) have also been described in the literature [2].

TS is a severe transient left ventricular dysfunction with regional wall motion abnormalities that may present with electrocardiogram (ECG) changes and/or elevated biomarkers in the absence of significant obstructive coronary artery disease [2-6]. This complex disease has a predilection to occur in females who are postmenopausal with a mean age of 67 years [3]. TS is frequently triggered

*Correspondence: Usama.n90@gmail.com

${ }^{2}$ Department of Internal Medicine, Sixth and Spruce Streets, Reading Hospital-Tower Health System, West Reading, PA 19612, USA

Full list of author information is available at the end of the article by emotional or physical stress that usually occurs 1-5 days prior to disease manifestation. Exogenous electrical stimuli (both accidental and therapeutic) have also been noted to precipitate this syndrome [7, 8]. Sudden catecholamine surge resulting in direct myocardial toxicity is a postulated mechanism for development of TS, a hypothesis supported by demonstration of twofold to threefold higher levels of catecholamines in TS as compared to patients with ST elevation myocardial infarction [9], and by the reported sensitivity of postmenopausal females to catecholamine surges $[10,11]$.

To better understand the association between direct current cardioversion and TS, we performed a systematic review of the literature for cases describing patients with TS following DC cardioversion and studied the patient demographics, procedural characteristics, and disease outcomes. original author(s) and the source, provide a link to the Creative Commons licence, and indicate if changes were made. The images or other third party material in this article are included in the article's Creative Commons licence, unless indicated otherwise in a credit line to the material. If material is not included in the article's Creative Commons licence and your intended use is not permitted by statutory regulation or exceeds the permitted use, you will need to obtain permission directly from the copyright holder. To view a copy of this licence, visit http://creativecommons.org/licenses/by/4.0/. 


\section{Methods}

\section{Search strategy}

We performed a comprehensive database search on MEDLINE (via PubMed), EMBASE, Google Scholar and Cochrane database of systematic reviews for case reports, case series and observational studies describing cases of Takotsubo cardiomyopathy or syndrome associated with synchronized direct current cardioversion from inception until January 1, 2020. The search strategy was performed using a concise vocabulary as shown in Supplementary files 1 and 2 .

\section{Study selection and characteristics}

Adult cases ( $>18$ years of age) which met Mayo Clinic Diagnostic Criteria for TS were included [6]. Cases with pharmacological cardioversion, unsynchronized cardioversion (defibrillation) and cases without cardioversion were excluded. Screening was performed by two independent authors (TAW, AA) with discrepancies resolved by a third author (UN). Additional hand search for references was also performed. After removal of duplicates, a total of 11 articles yielded 11 cases which were included in the systematic review. The included studies were all case reports [12-22].

Demographics, risk factors, clinical course, complications, and outcomes were extracted by four authors (TAW, AA, UN and AD). Analysis was performed via Microsoft Excel 2019 with continuous variables expressed as means with standard deviations or medians, where data were not normally distributed. Categorical variables were expressed as percentages. Data were analyzed for association between energy used in cardioversion and the time of onset of TS.

Baseline demographics of the included studies including age, sex, underlying comorbidities, cardioverted rhythm, energy of shock delivered, complications as well as time to development of these complications are outlined in Table 1

\section{Results}

The 11 cases of cardioversion-associated Takotsubo syndrome had female predominance $(91 \%)$ with a mean age of 76 years (SD: 8.37$)$. Palpitations $36 \%(n=4)$, chest pain $27 \%(n=3)$ and dyspnea $27 \%(n=3)$ were the most common presenting symptoms. Atrial fibrillation $73 \%(n=8)$

Table 1 Patient demographics and disease characteristics, NM: not mentioned

\begin{tabular}{|c|c|c|c|c|c|c|c|c|}
\hline Study & Age & Sex & Co morbidities & $\begin{array}{l}\text { Cardioverted } \\
\text { rhythm }\end{array}$ & $\begin{array}{l}\text { Joules } \\
\text { applied } \\
\text { HO }\end{array}$ & $\begin{array}{l}\text { Time to } \\
\text { develop TS } \\
\text { (hours) }\end{array}$ & Complications & $\begin{array}{l}\text { Cardiovascular, } \\
\text { inotropic or } \\
\text { mechanical support } \\
\text { needed }\end{array}$ \\
\hline Alishetti2018 [12] & 77 & $\mathrm{~F}$ & NM & Atrial flutter & 150 & $<1$ & $\begin{array}{l}\text { Cardiogenic shock, } \\
\text { heart failure }\end{array}$ & $\begin{array}{l}\text { Dopamine switched } \\
\text { to epinephrine drip }\end{array}$ \\
\hline Buchter [13] & 66 & $\mathrm{~F}$ & Hypertension & Atrial fibrillation & NM & NM & $\begin{array}{l}\text { Thromboembolism, } \\
\text { Cardiogenic shock }\end{array}$ & NM \\
\hline Eggleton 14] & 76 & $F$ & $\begin{array}{l}\text { Smoker, Hyperlipi- } \\
\text { demia, Hypertension }\end{array}$ & Atrial fibrillation & NM & 10 & $\begin{array}{l}\text { Pulmonary edema, } \\
\text { cardiogenic shock }\end{array}$ & Dopamine \\
\hline McCutcheon [15] & 87 & $F$ & $\begin{array}{l}\text { Hypertension, } \\
\text { Hyperlipidemia, } \\
\text { Mitral Valve Prolapse, } \\
\text { Chronic Kidney } \\
\text { Disease, }\end{array}$ & Atrial fibrillation & 100 & 28 & $\begin{array}{l}\text { Pulmonary edema, } \\
\text { Heart failure }\end{array}$ & None \\
\hline Pir [16] & 81 & $\mathrm{~F}$ & Hypertension & Atrial fibrillation & 150 & 48 & $\begin{array}{l}\text { Pulmonary edema, } \\
\text { Heart failure }\end{array}$ & None \\
\hline Shah [17] & 87 & $\mathrm{~F}$ & $\begin{array}{l}\text { Hypertension, } \\
\text { Hyperlipidemia }\end{array}$ & Atrial fibrillation & 200 & 24 & $\begin{array}{l}\text { Heart failure, Died } \\
\text { on post-hospital } \\
\text { follow-up }\end{array}$ & None \\
\hline Siegfried [18] & 67 & $\mathrm{~F}$ & Hypertension & Atrial fibrillation & 200 & NM & Cardiogenic shock & $\begin{array}{l}\text { Epinephrine, } \\
\text { vasopressin and } \\
\text { dobutamine }\end{array}$ \\
\hline Smyrlis [19] & 61 & $\mathrm{~F}$ & Hypertension & Atrial fibrillation & 120 & 4 & $\begin{array}{l}\text { Pulmonary edema, } \\
\text { Heart failure }\end{array}$ & None \\
\hline Vizzardi [20] & 81 & $F$ & $\begin{array}{l}\text { Hypertension, } \\
\text { Hyperlipidemia }\end{array}$ & Atrial fibrillation & NM & 24 & $\begin{array}{l}\text { Pulmonary edema, } \\
\text { Cardiogenic shock }\end{array}$ & $\begin{array}{l}\text { Dobutamine, dopa- } \\
\text { mine }\end{array}$ \\
\hline Zaghlol [21] & 73 & $M$ & $\begin{array}{l}\text { Hypertension, } \\
\text { Hyperlipidemia }\end{array}$ & Atrial flutter & 200 & 3 & $\begin{array}{l}\text { Heart failure, pulmo- } \\
\text { nary edema }\end{array}$ & None \\
\hline Valentino [22] & 84 & $F$ & Hypertension & Atrial flutter & NM & immediately & NM & NM \\
\hline
\end{tabular}


and atrial flutter $27 \%(n=3)$ were identified as the main etiologies prompting cardioversion.

Cardioversion was performed with a median energy level of 150 Joules (range: 100-200 Joules). Median time for TS development after cardioversion was $10 \mathrm{~h}$ (range: 0-48 h). Median peak troponin was 1.22 (range: 0.2$7.9 \mathrm{ng} / \mathrm{ml}$ ). Normal sinus rhythm was the most common rhythm identified at time of TS development, seen in 10 of 11 patients (91\%). T-wave inversion $27 \%(n=3), S T$ elevation $18 \%(n=2)$ and left bundle branch block $18 \%$ $(n=2)$ were the most prevalent EKG abnormalities. The mean ejection fraction was $25 \%$ in total 6 studies that mentioned this finding $[3,5,7-10](S D: \pm 9.5 \%$ at the time of TS diagnosis, with apical ballooning described in all the cases). ECG, echocardiogram, and coronary catheterization findings are described in Table 2.

Complications were described in 10 of the 11 patients (91\%). These included pulmonary edema in 6 of 11 (54\%), with 5 meeting criteria for cardiogenic shock of which 4 required inotropic support. Two patients also were reported to require ventilatory support.

Median time to recovery was 7 days. Seven of 11 made a complete recovery, and mean follow-up ejection fraction was 54\% (SD: $8 \%$ ) at a median of 7 days (3-11 days). One patient died from sudden cardiac death after hospital discharge but before follow-up.

\section{Discussion}

In this systematic review of DC cardioversion-associated TS, we identified similar demographics to prior TS reviews, in which female predominance is common ranging from 87 to $89.8 \%(23,24)$, supporting the hypothesis of postmenopausal female sensitivity to catecholamine surge $[10,11]$. The mean age reported in the included studies was 76.4 years (SD: 8.78) which is slightly higher than previously reported registry-based study [23].

ST elevation and T-wave inversions were the most prevalent electrocardiogram abnormalities, similar to previous studies [23, 24]. Interestingly we noted a slightly higher rate of left bundle branch block (18\%), compared to $9 \%$ reported in a previous larger registry [25]. We also found profound systolic myocardial dysfunction in the included studies with an average ejection fraction of $25 \%$ (SD: $9.5 \%$, compared to ejection fraction of $33-40 \%$ in previously reported cases [23, 24, 26]). We also found that our cohort had higher rates of both cardiogenic shock (45\%) and pulmonary edema (50\%) than is reported in larger series of TS, in which cardiogenic shock is seen in $9.3 \%$ [2, 24] and pulmonary edema in only $25 \%$ [24].

Takotsubo in our cohort was identified after a median time of $10 \mathrm{~h}$ and median cardioversion energy of 150 (range: 100-200 Joules). We could identify no direct relation with energy administered to the time to development of Takotsubo syndrome. Pad placement could not be evaluated, given inconsistent reporting in the included studies. Excess epinephrine and norepinephrine release from the adrenal medulla and sympathetic nervous system is hypothesized to induce direct myocardial injury in TS $[9,27,28]$. The excess catecholamines are postulated to increase systemic vascular resistance and increase afterload on an already "stressed" myocardium. However, it remains unknown how electrical cardioversion leads to direct or indirect myocardial toxicity leading to the development of TS. We hypothesize the mechanism may be similar to previously reported cases of TS resulting from electroconvulsive therapy and lightening $[7,8$, 29]. Electrical current induces excess autonomic and catecholamine surge which can result in myocardial stunning and coronary vasospasm via proteolysis of contractile apparatus or desensitization of these filaments due to excess intra-cellular calcium release [30]. In our population, direct current would have served as the electrical stimuli for myocardial contractile protein denaturation and saturation of the adrenergic receptors with catecholamines triggering TS. We postulate that the combination of direct myocardial injury from the electrical stimulus in combination with catecholamine surge may have resulted in hyperacute development of TS post-cardioversion.

Study Limitations: The sample size was a major limitation in analyzing our data. The authors were restricted to the limited information provided in the case descriptions. The review was limited to direct current cardioversion, and therefore, our findings cannot be generalized for other cardiac procedures or electricity-triggered TS. Intentional defibrillation for ventricular arrhythmias was excluded from the study to prevent skewing of data. Therefore, result from this review cannot be expanded to unsynchronized cardioversion. Given the limited followup, we were unable to determine if repeat cardioversions were attempted with the recurrence of Takotsubo syndrome. Moreover, it is possible that the sicker patients reported in our review predisposes to some degree of publication bias as subclinical TS may have not been diagnosed or reported post-cardioversion.

The findings in our review did not reveal any other predisposing factor for the development of TS apart from the age and female gender. The details of other precipitants for TS such as neurological and psychiatric disease elements were not reported in the included studies which may have played a confounding role.

We highlight the importance of closer inpatient and outpatient monitoring of the geriatric population after cardioversion especially during the first $24 \mathrm{~h}$ for early detection of TS and appropriate intervention. Patients 


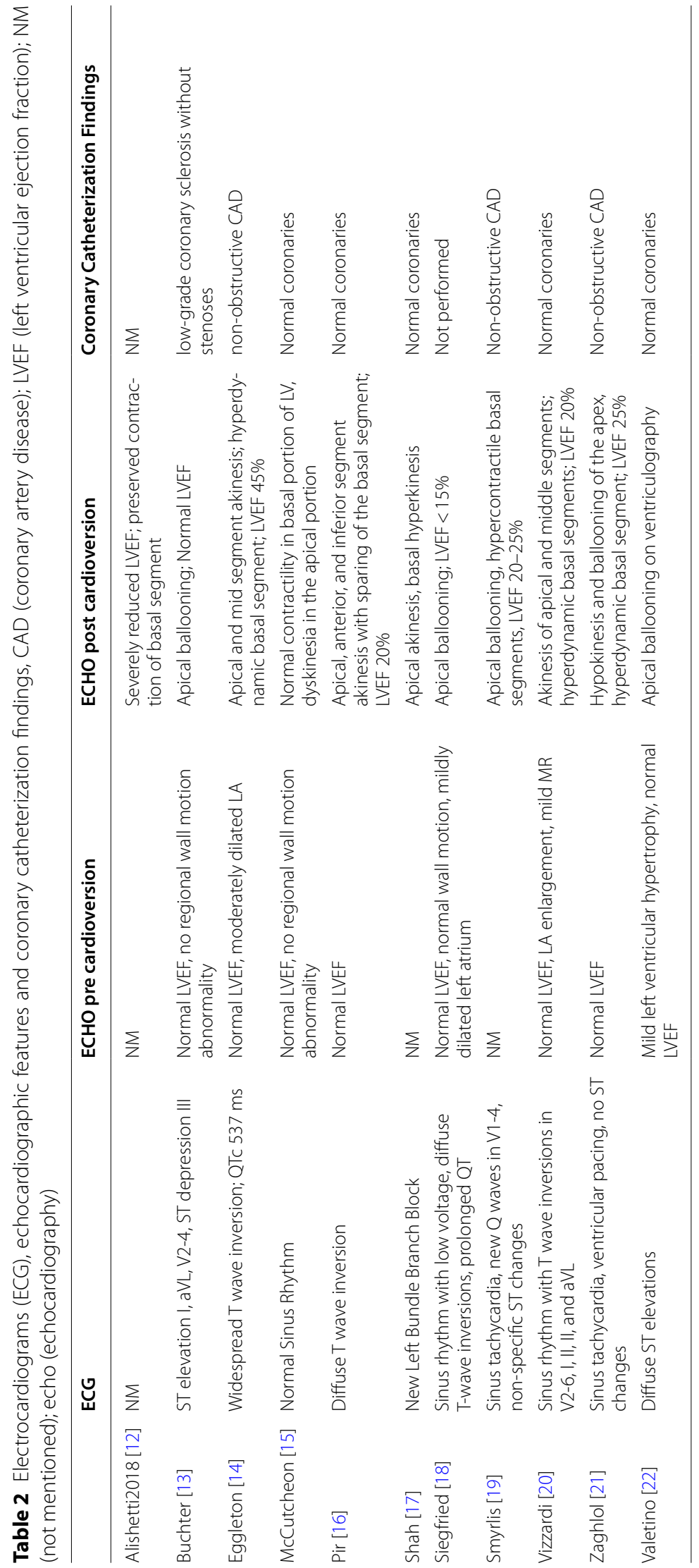


may also be counselled about this rare complication when obtaining procedural consent for direct current cardioversion.

\section{Conclusion}

Cardioversion-associated TS has an overall favorable outcome with complete recovery in most cases. Nonetheless, chest pain and heart failure symptoms may be a manifestation of post-cardioversion TS, especially in elderly females. A higher risk of this complication may exist for elderly females undergoing synchronized cardioversion.

\section{Abbreviations}

DC: Direct current; TS: Takotsubo syndrome.

\section{Supplementary Information}

The online version contains supplementary material available at https://doi. org/10.1186/s42444-021-00055-7.

Additional file 1. Search strategy.

Additional file 2. Prisma diagram.

\section{Acknowledgements}

We acknowledge Alexandra Short, MS, MLIS, for assistance in crafting the search strategy.

\section{Authors' contributions}

Tayyab Ali Waheed contributed to writing original draft, conceptualization, literature search and data curation. Usama Nasir contributed to writing original draft, conceptualization, literature search and data curation. Ansar Aziz contributed to data extraction, writing and editing. Haseeb Chaudhary contributed to statistics, critical review and revision of manuscript. Anthony Donato contributed to forming research strategy, editing and supervision. All authors read and approved the final manuscript.

\section{Funding}

None.

\section{Availability of data and materials}

Present as Additional files 1 and 2.

\section{Declarations}

Ethical Approval and Consent to participate

Not Applicable.

\section{Consent for publication}

Not Applicable.

\section{Competing interests}

Not Applicable.

\section{Author details}

'Department of Cardiovascular Disease, Reading Hospital-Tower Health System, West Reading, USA. ${ }^{2}$ Department of Internal Medicine, Sixth and Spruce Streets, Reading Hospital-Tower Health System, West Reading, PA 19612, USA ${ }^{3}$ Department of Hospital Medicine, Reading Hospital-Tower Health, West Reading, USA. ${ }^{4}$ Professor of Medicine, Drexel University College of Medicine, Philadelphia, USA
Received: 18 August 2021 Accepted: 28 October 2021

Published online: 16 February 2022

\section{References}

1. Reiffel JA. Cardioversion for atrial fibrillation: treatment options and advances. Pacing Clin Electrophysiol. 2009;32(8):1073-84.

2. Lyon AR, Bossone E, Schneider B, Sechtem U, Citro R, Underwood SR, et al. Current state of knowledge on Takotsubo syndrome: a Position Statement from the Taskforce on Takotsubo Syndrome of the Heart Failure Association of the European Society of Cardiology. Eur J Heart Fail. 2016;18(1):8-27.

3. Medina de Chazal H, Del Buono MG, Keyser-Marcus L, Ma L, Moeller FG, Berrocal D, et al. Stress Cardiomyopathy Diagnosis and Treatment. <span class="subtitle" $><$ em $>$ JACC $</$ em $>$ State-of-the-Art Review $</$ span $>$. 2018;72(16):1955-71.

4. Ghadri J-R, Wittstein IS, Prasad A, Sharkey S, Dote K, Akashi YJ, et al. International expert consensus document on Takotsubo syndrome (part I): clinical characteristics, diagnostic criteria, and pathophysiology. Eur Heart J. 2018;39(22):2032-46.

5. Ghadri J-R, Wittstein IS, Prasad A, Sharkey S, Dote K, Akashi YJ, et al. International expert consensus document on Takotsubo syndrome (part II): diagnostic workup, outcome, and management. Eur Heart J. 2018;39(22):2047-62

6. Prasad A, Lerman A, Rihal CS. Apical ballooning syndrome (Tako-Tsubo or stress cardiomyopathy): a mimic of acute myocardial infarction. Am Heart J. 2008;155(3):408-17.

7. Hayashi M, Yamada H, Agatsuma T, Nomura H, Kitahara O. A case of takotsubo-shaped hypokinesis of the left ventricle caused by a lightning strike. Int Heart J. 2005:46(5):933-8.

8. Narayanan A, Russell MD, Sundararaman S, Shankar KK, Artman B. Takotsubo cardiomyopathy following electroconvulsive therapy: an increasingly recognised phenomenon. BMJ Case Rep. 2014;2014.

9. Wittstein IS, Thiemann DR, Lima JA, Baughman KL, Schulman SP, Gerstenblith $\mathrm{G}$, et al. Neurohumoral features of myocardial stunning due to sudden emotional stress. N Engl J Med. 2005;352(6):539-48.

10. Sachdev E, Bairey Merz CN, Mehta PK. Takotsubo Cardiomyopathy. Eur Cardiol. 2015;10(1):25-30.

11. Hart EC, Charkoudian N, Wallin BG, Curry TB, Eisenach J, Joyner MJ. Sex and ageing differences in resting arterial pressure regulation: the role of the beta-adrenergic receptors. J Physiol. 2011;589(Pt 21):5285-97.

12. Alishetti $S$, Beyer A, Hongo R. Electric shock and cardiogenic shock: a case of Dc cardioversion resulting in stress cardiomyopathy. J Am Coll Cardiol. 2018;71(11 Supplement):A2366.

13. Buchter B, Khattab AA, Richardt G. Coronary embolism with apical ballooning complicating electrical cardioversion-is it part of the apical ballooning syndrome? Case report and review of the literature. Herz. 2006;31(5):480-4.

14. Eggleton S, Mathur G, Lambros J. An unusual precipitant of tako-tsubo cardiomyopathy. Heart Lung Circ. 2008;17(6):512-4.

15. McCutcheon K, Butler I, Vachiat A, Manga P. Takotsubo syndrome in an elderly woman due to electrical cardioversion. Int J Cardiol. 2016;224:69-71.

16. Pir MS, Saqib N, Oza F, Rao M. latrogenic heartbreak: stress cardiomyopathy after electrical cardioversion. J Am Coll Cardiol. 2019;73(9 Supplement 1):2701.

17. Shah JJ, Ostwani W, Angiolillo D, Franchi F. Stress cardiomyopathy induced by electrical cardioversion: should we change our current clinical practice? J Am Coll Cardiol. 2018;71(11 Supplement):A2535.

18. Siegfried JS, Bhusri S, Guttenplan N, Coplan NL. Takotsubo cardiomyopathy as a sequela of elective direct-current cardioversion for atrial fibrillation. Tex Heart Inst J. 2014;41(2):184-7.

19. Smyrlis A, Yaranov D, Galin I, Khan S, Alexander J. Recurrent direct current cardioversion induced takotsubo cardiomyopathy. Int Cardiovasc Forum J. 2015;3:32.

20. Vizzardi E, Rovetta R, Bonadei I, Quinzani F, D’Aloia A, Salghetti F, et al. A case of Tako-Tsubo cardiomyopathy after electrical cardioversion. Minerva Med. 2013;104(1):115-7. 
21. Zaghlol R, Hritani R, O'Donoghue S. Shock begets shock: a case of direct current cardioversion-induced takotsubo cardiomyopathy. HeartRhythm Case Rep. 2019;5(6):310-3.

22. Di Valentino M, Mocetti M, Previsdomini M, Biasco L. A rare complication of electric cardioversion in an elderly patient "Electrical Takotsubo." Cardiovascular Medicine. 2018;21(03):78-81.

23. Templin C, Ghadri JR, Diekmann J, Napp LC, Bataiosu DR, Jaguszewski M, et al. Clinical features and outcomes of takotsubo (Stress) cardiomyopathy. N Engl J Med. 2015:373(10):929-38.

24. Singh K, Carson K, Shah R, Sawhney G, Singh B, Parsaik A, et al. Metaanalysis of clinical correlates of acute mortality in takotsubo cardiomyopathy. Am J Cardiol. 2014;113(8):1420-8.

25. Parodi G, Salvadori C, Del Pace S, Bellandi B, Carrabba N, Gensini GF, et al. Left bundle branch block as an electrocardiographic pattern at presentation of patients with Tako-tsubo cardiomyopathy. J Cardiovasc Med (Hagerstown). 2009;10(1):100-3.

26. Nazir S, Lohani S, Tachamo N, Ghimire S, Poudel DR, Donato A. Takotsubo cardiomyopathy associated with epinephrine use: A systematic review and meta-analysis. Int J Cardiol. 2017;229:67-70.
27. Akashi YJ, Goldstein DS, Barbaro G, Ueyama T. Takotsubo cardiomyopathy: a new form of acute, reversible heart failure. Circulation. 2008;118(25):2754-62.

28. Ono R, Falcao LM. Takotsubo cardiomyopathy systematic review: Pathophysiologic process, clinical presentation and diagnostic approach to Takotsubo cardiomyopathy. Int J Cardiol. 2016;209:196-205.

29. Celano CM, Torri A, Seiner S. Takotsubo cardiomyopathy after electroconvulsive therapy: a case report and review. J ect. 2011;27(3):221-3.

30. Mclntyre WF, Simpson CS, Redfearn DP, Abdollah H, Baranchuk A. The lightning heart: a case report and brief review of the cardiovascular complications of lightning injury. Indian Pacing Electrophysiol J. 2010;10(9):429-34.

\section{Publisher's Note}

Springer Nature remains neutral with regard to jurisdictional claims in published maps and institutional affiliations.
Ready to submit your research? Choose BMC and benefit from:

- fast, convenient online submission

- thorough peer review by experienced researchers in your field

- rapid publication on acceptance

- support for research data, including large and complex data types

- gold Open Access which fosters wider collaboration and increased citations

- maximum visibility for your research: over $100 \mathrm{M}$ website views per year

At BMC, research is always in progress.

Learn more biomedcentral.com/submissions 